\title{
INFLUENCE OF SOIL CONSERVATION TECHNIQUES ON GROWTH AND YIELD OF MAIZE (Zea mays L.) IN TERAI REGION OF WEST BENGAL
}

\author{
B. De ${ }^{* 1}$ and S. Bandyopadhyay \\ Department of Agronomy, Uttar Banga Krishi Viswavidyalaya, Pundibari Cooch Behar 736165, West \\ Bengal, India
}

\begin{abstract}
The climate of the terai region of West Bengal, India in general, is subtropical par humid to tropical with light textured acid soil with the problems like low moisture retention, low water use efficiency, leaching of bases, soil erosion, limited availability of multiple plant nutrients and restricted activity of beneficial soil micro-organisms. To combat these soil health related problems and to improve the overall productivity of North Bengal, a comparison between the conventional and conservation tillage was taken up and the immediate results were measured in terms of growth, yield attributes and yield. In the first two years of experimentation, though different growth attributes, grain yield, stover yield, and different yield attributing characters such as kernel rows $\mathrm{cob}^{-1}$, number of kernels row ${ }^{-1}, 100$ seed weight $(\mathrm{g})$, number of seeds $\mathrm{cob}^{-1}$, girth of cob, length of cob and number of effective cob plant ${ }^{-1}$ were higher in conventional tillage as compared to conservation tillage but in terms of soil heath characteristics, conservation tillage had a meaningful remark from the initial years towards the future food security. Mulching @ $4 \mathrm{t} \mathrm{ha}^{-1}$ was found to have performed better than unmulched treatments. Application of $75 \%$ recommended dose of fertilizer + Vermicompost @ $10 \mathrm{t} \mathrm{ha}^{-1}$ resulted in better growth and yield attributes which directly influenced to have higher grain and stover yield.
\end{abstract}

Key words: Soil conservation technique, zero tillage, straw mulching, vermicompost, maize, stover and grain yield.

\footnotetext{
* Corresponding author email: biman_de@rediffmail.com

${ }^{1}$ INSPIRE Fellow, Department of Agronomy, Uttar Banga Krishi Viswavidyalaya, Pundibari Cooch Behar 736165, West Bengal, India
}

Received: 25.03.2013 


\section{INTRODUCTION}

The decline in the soil quality is a major concern, not only in the context of maintaining food production, but also with regard to the quality of the environment. The climate of the terai region of West Bengal, in general, is sub-tropical par humid to tropical humid in nature with distinctive characteristics of high rainfall, high relative humidity accompanied by low temperature. Light textured acid soil of North Bengal occasionally faces the problems like low moisture retention, low water use efficiency, leaching of bases, soil erosion, limited availability of multiple plant nutrients and restricted activity of beneficial soil micro-organisms. To combat these soil health related problems and to improve the overall productivity of West Bengal, the possible approaches are conservation tillage, mulching and incorporation of sufficient amount of good quality organic matter. In traditional agriculture, the aim of tillage can be summarized as to create a suitable seedbed, kill weeds, for reducing competition and conserving water and remove restrictions to infiltration, drainage and root growth within the root zone. The soil physical environment is important for maintaining sustained agronomic production; a concept embodied in the presumption that good soil tilth is a precursor to high crop productivity (Russel, 1971). No till has been widely claimed as highly effective practice for conservation of soil and water as compared to conventional tillage. Greater retention of water in soil profile under conservation tillage has been reported (Moreno et al., 1997). Conservation tillage usually changes soil organic matter distribution in the A-Horizon (Angers et al., 1997). Application of sufficient amount of organic matter is the key for the improvement of soil physical, chemical \& biological environment (Hebbarai et al., 2006). Gradual deterioration of agricultural soil health was due to inherent soil problems which are noticeable as light textured soil, high rainfall (2000 $\mathrm{mm}$ to 3500 $\mathrm{mm}$ ), strongly acidic soil ( $\mathrm{pH} 4.0-6.0$ ) leads to low moisture retention capacity, low water use efficiency, leaching of bases, low nutrient holding capacity leading to poor nutrient use efficiency, soil erosion, limits the availability of plant nutrients and restricts the activity of beneficial soil micro-organisms and also due to faulty agricultural practices such as heavy tillage. Adopting this technology leads to exhausting soil carbon pool rapidly- resulting from oxidation of carbon and emission in the form of $\mathrm{CO}_{2}$, poor tendency of farmers for incorporation of organic manures, poor quality and insufficient quantity of organic manures.

The present investigation was planned to determine the effect of different tillage systems in combination with mulch application on some soil physical properties and growth of maize. So considering the above situations some manipulation in terms of tillage, mulching and nutrient management practices needs to be experimented to counteract the adverse soil condition and to improve the productivity of maize as a potential cereal crops in West Bengal agro-climatic region 


\section{MATERIALS AND METHODS}

\section{Location and soil condition}

The experiment was carried out at Instructional Farm of Uttar Banga Krishi Viswavidyalaya, Pundibari, Cooch Behar, West Bengal, India during two consecutive years 2010 and 2011. The farm is situated at $26^{\circ} 19^{\prime} 86^{\prime \prime} \mathrm{N}$ latitude and $89^{\circ} 23^{\prime} 53^{\prime \prime} \mathrm{E}$ longitude and at an altitude of 43 meters above mean sea level. The soil is sandy loam (62-65\% sand, $18 \%$ silt, $16-17 \%$ clay), acidic with a $\mathrm{pH}$ of $5.85,0.52 \%$ organic carbon, available nitrogen (217.65 kg ha-1), available phosphorus (22.82 $\left.\mathrm{kg} \mathrm{ha}^{-1}\right)$, and available potash (174.68 $\left.\mathrm{kg} \mathrm{ha}^{-1}\right)$.

\section{Agro-climatic condition of the research farm}

The climate of terai zone is sub-tropical in nature with distinctive characteristics of high rainfall, high humidity and a prolonged winter. There are two dominant seasons in a year - an extended winter or dry spring and a long rainy season. Very low rainfall, cool temperature and dry clear sunny days, with occasional heavy rainfall and high humidity are the characteristics of winter season. The winter, in most of the years falls in January and is extended even upto March. The rainy season is characterized by hot and humid weather, heavy precipitation by south-west monsoon with cloudy overcast days and fewer hours of bright sunshine.

\section{Field experiment}

The experiment was laid out in split-split plot design with three replications having two main-plot treatments $\left(\mathrm{C}_{1}=\right.$ conventional tillage and $\mathrm{C}_{0}=$ zero tillage), two subplot treatments $\left(\mathrm{M}_{1}=\right.$ wheat straw mulching @ $4 \mathrm{Mg} \mathrm{ha}^{-1}$ and $\mathrm{M}_{0}=$ un mulched) and four sub-sub plot treatments $\left(\mathrm{V}_{1}=75 \% \mathrm{RD}+\right.$ Vermicompost @ 5t ha ${ }^{-1} ; \mathrm{V}_{2}=75 \% \mathrm{RD}+$ Vermicompost @ 7.5t ha ${ }^{-1} ; \mathrm{V}_{3}=75 \%$ RD + Vermicompost @ 10t ha ${ }^{-1}$, and $\mathrm{V}_{4}=100 \%$ RD where RD is a recommended dose of fertilizers @ of 120-60-60 NPK kg ha ${ }^{-1}$ ). A net plot size was $3 \mathrm{~m}$ x $4 \mathrm{~m}$. Maize cultivar “Adiquba” was sown with spacing of $30 \mathrm{~cm} \mathrm{X} 10 \mathrm{~cm}$. Nitrogen, phosphorus and potassium were applied in the form of Urea, SSP and MOP. Full dose of $\mathrm{P}_{2} \mathrm{O}_{5},{ }_{1} /{ }^{\text {rd }}$ of $\mathrm{K}_{2} \mathrm{O}$, and $1 /{ }^{1}$ rd of nitrogen were applied as basal dose. Then $1 / 3$ rd of nitrogen and potassium was applied as top dressing after completion of the first weeding/thinning, and the remaining $1 / 3^{\text {rd }}$ at 45 days after sowing (DAS).

\section{Statistical analysis}

The data collected on growth and yield from the field and laboratory were subjected to statistical analysis appropriate to the design and the treatment variations were tested for significance by ' $F$ ' test (Cochran and Cox, 1955; Gomez and Gomez, 1983). The standard error of mean and critical differences are indicated in the tables. For determination of critical differences at 5\% level of significance, Fisher and Yates (1963) tables were consulted. 


\section{RESULTS AND DISCUSSION}

\section{Maize growth}

The crop growth attributes such as, plant height, dry matter accumulation (DMA), crop growth rate (CGR), leaf area index (LAI), leaf area duration (LAD), net assimilation rate (NAR), on the average were influenced by tillage, mulch and application of vermicompost (Figures 1 to 5). Significantly higher crop growth corresponding to all parameters was observed under conventional tillage (CT) over zero tillage (ZT). The possible reason might be due to that conventional tillage (CT) develops suitable environment for root penetration whereas there is a mechanical impedance of roots in zero tillage system. Blecharczyk et al., (2004) and Khurshid et al., 2006 observed lower plant height in case of zero tillage as compared to conventional systems in light textured soils. The biomass and LAI were, therefore, higher in CT plots than other plots in the later stages of maize development (Figure 4) because of grain yield being highest under CT during 2010 and 2011. However, in 2011 higher soil water storage at sowing and throughout the seasons under ZT plots enhanced maize development and growth. Moreover, no peculiar diseases or pests were detected in the CT plots but infestation was observed in ZT plots. After three consecutive years of no-tillage practice due to the improvement of physical properties of the soil, the penetration resistance become much favourable to the root growth in the non-tilled plot, as reported by Izumi et al. (2004) and might be due to the surface cover of crop residues on zero tilled plots in the first year, which may have slowed down the rise of soil temperature (Khan and Parvej, 2010; Liu et al., 2004 and Khurshid et al., 2006) and delayed maize development and growth in the first year than the second year. This decrease in biomass yield was also attributed to significantly higher number of weeds $\left(\mathrm{m}^{-2}\right)$ and weed biomass $\left(\mathrm{g} \mathrm{m}^{-2}\right)$ under zero tilled plots. Dogra et al. (2002) reported that conservation tillage operations in maize check erosion but caused more weed growth, thereby leading to decreased productivity and profitability. Other secondary growth parameters such as CGR, LAD and NAR also followed the same trend because of the above elaborated facts (Izumi et al., 2004; Barik et al., 2006 and Wang et al., 2011).

Higher growth was observed in case of mulching @ $4 \mathrm{mg} \mathrm{ha}^{-1}$ treatment than un-mulched treatment. Similar findings were noticed by Singh et al. (2011), Wang et al. (2011) and Mesfine et al. (2005). These results are also in agreement with those of Liu et al., (2002), Shittu and Fasina, (2006) and Mesfine et al. (2005) who concluded that crop residue on the soil increased soil water contents, improved the ecological environment of the field and increased the grain yield of maize. Pervaiz et al. (2009) also reported that maize grew taller under greater mulch levels because of availability of more soil moisture contents for plant growth. Mulch moderates soil temperature and increases water infiltration during intensive rain (Gajri et al., 1994). Biomass yield and plant height of maize increased in wheat straw mulch over no mulch to the extent $17.90-25.57 \%$ and $18.23-17.74 \%$ respectively at both the years of 
investigation. Again, in case of CGR, LAI, LAD and NAR similar results were reported by Yi et al., (2007). They stated that straw mulching increased plant height, leaf area, dry matter weight and increased root activity (Figures 2, 3, 4 and 5). Sharma et al. (2009) and Pervaiz et al. (2009) also reported that straw mulch was more effective in maize than without mulch.

Among the nutritional treatments, the highest growth of crop at harvest was observed in treatment receiving vermicompost @ $10 \mathrm{t} \mathrm{ha}^{-1}$ in combination with 75\% recommended dose of fertilizer (RDF) followed by Vermicompost @ $7.5 \mathrm{t} \mathrm{ha}^{-1}$ along with 75\% RDF, Vermicompost @ $5 \mathrm{t} \mathrm{ha}^{-1}$ along with 75\% RDF and 100\% RDF which also were in conformity with the findings of Barik et al. (2006), Shukla and Tyagi, (2009). Net assimilation rate varied non-significantly between the nutrient management treatments. Hebbarai et al. (2006) revealed that highest growth was recorded under $100 \%$ recommended dose of fertilizer + vermicompost application that however remained at par with $75 \%$ recommended dose of fertilizer + vermicompost and $100 \%$ recommended dose of fertilizer alone. Reduction in recommended dose of fertilizer beyond $75 \%$ resulted in significantly lower yields. Slow organic matter decomposition through changes in nutrient mineralization/immobilization improved the soil fertility and the potential nutrient supply to the growing cultivated crops (Gosai et al., 2010). This again explained the reason behind greater plant and soil nutrients from organic matter which helped in overall growth and production of maize crop.

\section{Maize yield attributing characters}

Data regarding the yield attributing characters (Table 1-a, b) such as number of kernel rows $\mathrm{cob}^{-1}$ of maize, kernels row ${ }^{-1}, 100$ seed weight, number of seeds $\mathrm{cob}^{-1}$ and length of cob where conventional and zero tillage were statistically non-significant with each other, whereas, in case of number of effective cob plant ${ }^{-1}$ and girth of cob were found to be significantly different from each other. Su et al., (2007) and Izumi et al., (2004) also found parallel observations. Izumi et al., (2004) reported that continuous no-tillage practice gradually improved the soil condition for the root system development and furthermore, enhanced the crop growth and yield, which might be directly due to the increase in yield attributing characteristics. They also added that root growth was improved after consecutive years of no-tillage practice due to the improvement of the physical properties of the soil; the penetration resistance became much favourable to the root growth in the non-tilled plots. Therefore, in maize the reduction in productivity resulting from the no-tillage practice was improved by alleviating the restraint of root growth (Khurshid et al., 2006). As regards mulching @ $4 \mathrm{mg} \mathrm{ha}^{-1}$, the yield attributing characters such as number of kernel rows $\mathrm{cob}^{-1}$, kernels row ${ }^{-1}, 100$ seed weight and number of seeds $\mathrm{cob}^{-1}$, where mulching and unmulched were statistically significant with each other, whereas, in case of length of cob of maize, number of effective cobs plant ${ }^{-1}$ and girth of cob were found to be non-significant with each other (Table 1-a, b and 2). Yi et al. 
(2007) and Wang et al. (2011) reported that straw mulching increased 100-seed weight and yield attributing characters. They concluded that the effects of full-straw mulching were better than those of half-straw mulching indicating that it might be due to the increased soil moisture content (27.88 and $27.61 \%$ higher) during two years of experimentation. The possible reason may be that wheat straw mulches generated favourable soil temperature and soil moisture conditions which, in turn, increased the dry matter accumulation in plant (Khan and Pervej, 2010 and Wang et al., 2011).

The application of vermicompost throughout the yield attributing characters attained on average non-significant values. The highest yield attributes were recorded with treatments receiving vermicompost @ $10 \mathrm{t} \mathrm{ha}^{-1}$ in combination with 75\% recommended dose of fertilizer (RDF) which were at par with treatments $\mathrm{V}_{2}$ followed by $\mathrm{V}_{1}$ and $\mathrm{V}_{4}$. Experiments by Gopinath et al. (2008) and Das et al. (2010) confirmed it. It was indicative of the fact that Vermicompost in conjunction with nitrogen, phosphorus, potassium exhibited their role in various physiological functions, movement of growth regulators within the plant, germination and growth of pollen grains and pollen tubes (Hebbarai et al., 2006; Patil and Sheelavantar, 2006 and Gopinath et al., 2008). In an experiment conducted by Shukla and Tyagi, 2009, the added organic materials, like vermicompost and enriched compost increased germination and growth of shoots, roots coupled with enhanced nodulation in legumes and promoting higher yield and yield attributes where slightly greater benefits were derived with vermicompost as compared to enriched compost.

In case of number of kernels row ${ }^{-1}$, tillage-mulch interaction was significant during both years whereas tillage-vermicompost and mulch-vermicompost interactions were not significant but kernel rows $\mathrm{cob}^{-1}, 100$ seed weight (gm), number of seeds $\mathrm{cob}^{-1}$, girth of cob (mm), length of cob and number of effective cob plant ${ }^{-1}$ were found to be non-significant during both years.

\section{Maize yield}

Data pertaining to grain yield (Table-2) of maize showed the influence of tillage, mulch and combination of recommended dose of fertilizers and vermicompost levels on grain yield. In case of tillage, conventional tillage differed non-significantly from zero tillage during both years. The maximum mean value of grain production was observed in conventional tillage which was non-significant with that of zero tillage during both years. Ressia et al. (2000), Motavalli et al. (2003) \& Okeleye and Oyekanmi (2003) confirmed these findings. As regards mulch, significant grain yield was observed in treatment where mulch was applied compared with unmulched during both years. There were 12.12 and $8.38 \%$ increase in grain yield under mulching@4 mg ha ${ }^{-1}$ condition as compared to unmulched or control treatment respectively during two years. Results corroborated the findings of Parasuraman (2002), Mesfine et al. (2005) and Sharma et al. (2009). Application of vermicompost also showed significant variation during both years. There were 24.35 and $26.57 \%$ 
increase in yield in 75\% RD + Vermicompost @ $10 \mathrm{t} \mathrm{ha}^{-1}$ as compared to 100\% recommended dose respectively during both years. The highest grain yield was recorded with treatments receiving vermicompost @ $10 \mathrm{t} \mathrm{ha}^{-1}$ in combination with $75 \%$ recommended dose of fertilizer which was at par with treatment $V_{2}$ followed by $\mathrm{V}_{1}$ and $\mathrm{V}_{4}$. Hebbarai et al. (2006), Patil and Sheelavantar, (2006) and Gopinath et al. (2008) showed similar results.

Stover yield in conventional tillage system was at par with that of zero tillage (Table 2). Results are in conformity with those of Blecharczyk et al. (2006) for the initial years but long term study done by Hati et al. (2006) revealed higher biomass yield in the conservation tillage. There were 16.12 and $7.42 \%$ increase in biological yield of maize under conventional tillage as compared to zero tillage during both years, respectively. The effect of mulches and vermicompost was significant on biological yield of maize (Table 2). Similarly, significant biological yield was recorded in the mulching @ $4 \mathrm{mg} \mathrm{ha}^{-1}$ conditions as compared to unmulched conditions. Similar findings are put forward by Pervaiz et al. (2009). Among the nutritional treatments, treatment receiving vermicompost @ $10 \mathrm{t} \mathrm{ha}^{-1}$ in combination with 75\% recommended dose of fertilizer varied significantly from vermicompost @ $7.5 \mathrm{t} \mathrm{ha}^{-1}$ along with 75\% RD,. vermi compost @ $5 \mathrm{t} \mathrm{ha}^{-1}$ along with 75\% RDF and $100 \%$ RDF. Khandgave (2002) corroborated similar findings. Interactions of tillagemulch, tillage-vermicompost and mulch-vermicompost were insignificantly different for grain and stover yields during both years of investigation.

The higher harvest index of maize (46.86 and $46.03 \%$ ) in both the experimental season were achieved in conventional tillage system (CT) compared to zero tillage (ZT) Similarly, higher harvest index was recorded under mulching @ 4 mg ha ${ }^{-1}$ conditions (41.53 and $39.58 \%$ ) compared to unmulched conditions (38.85 and $38.45 \%$ ) during both the years of experimentation (Table 2). Among the nutrient management treatments highest harvest index (40.78 and $40.58 \%$ ) was recorded at treatments receiving vermicompost @ $10 \mathrm{t} \mathrm{ha}^{-1}$ in combination with 75\% recommended dose of fertilizer followed by vermicompost @ $5 \mathrm{t} \mathrm{ha}^{-1}$ in combination with 75\% recommended dose of fertilizer, vermicompost @ $7.5 \mathrm{t} \mathrm{ha}^{-1}$ in combination with $75 \%$ recommended dose of fertilizer and $100 \%$ recommended dose in the ratio of 120: 60: 60 respectively during two years of experimentation.

\section{CONCLUSION}

Comparatively stable production comparable to the conventional tillage can be achieved by zero tillage practice in maize in typical North Bengal terai climates in spite of the large fluctuation in the growth system. Again, in maize, zero tillage practice gradually improves the soil conditions for the root systems development and consequently, enhances the shoot growth and seed yield. 


\section{REFERENCES}

Angers, D.A., Bolinder, M.A. Carter, M.R., Gregorich, E.G., Drucy, C.F., Liang, B.C., Voroney, R.P., Simard, R.R., Donald, R.G., Beyaet R.P., Marted J.1997. Impact of tillage practices on organic carbon and nitrogen storage in cool, humid soils of eastern Canada. Soil and Tillage Research, 41: 191-201.

Barik, A.K., Das, A., Giri, A.K., Chattopadhyay, G.N.2006. Effect of integrated plant nutrient management on growth, yield and production economics of wet season rice (Oryza sativa). Indian Journal of Agricultural Sciences, 76 (11): 657-60.

Blecharczyk, A., Maecka, I., Skrzypczak, G., 2004. Effect of reduced tillage on yield, weed infestation of maize and soil properties. Acta Scientiarum Polonorum Agric, 3(1): 157163.

Cochran, G.W., Cox, M.G., 1955. Experimental Designs, John Wiley and Sons Inc., USA.

Das, A., Baiswar, P., Patel, D.P., Munda, G.C., Ghosh, P.K. and Chandra, S. 2010. Productivity, nutrient harvest index, nutrient balance sheet and economics of lowland rice (Oryza sativa) as influenced by composts made from locally available plant biomass. Indian Journal of Agricultural Sciences, 80 (8): 686-90.

Dogra, P., Joshi, B.P., Sharma, N.K., 2002. Economic analysis of tillage practices for maize cultivation in the Himalayan humid subtropics. Indian Journal of Soil Conservation, 30(2):172-178.

Fisher, R.A., Yates, F., 1963. Statistical Tables for Biological, Agricultural and Medical Research. Sixth edition. Oliver and Boyd. Fdiburgh Tweedale court, London.

Gajri, P.R., Arora, V.K., Chaudhary, M.R., 1994. Maize growth, response to deep tillage, straw mulching and farmyard manure in coarse textured soils of N. W. India. Soil Use and Mgt, :10, 15-20.

Gomez, K.A. and Gomez, A.A. 1983 Statistical procedures for agricultural research. John Wiley and sons, New York.

Gopinath, K.A., Saha, S., Mina, B.L., Harit P., Kundu, S., Gupta, H.S., 2008. Influence of organic amendments on growth, yield and quality of wheat and on soil properties during transition to organic production. Nutrient Cycling in Agroecos, 82(1): 51-60.

Gosai, K., Arunachalam A., Dutta, B.K., 2010. Tillage effects on soil microbial biomass in a rainfed agricultural system of northeast India. Soil and Tillage Research, 109: 68-74.

Hebbarai, M., Ganiger, V.M., Reddy, B.G.M., Joshi, V.R.2006. Integrated nutrient management sapota [Manilkara zapota] using vermicompost to increase yield and quality. Indian Journal of Agricultural Sciences, 76 (10): 587-90.

Izumi, Y, Uchida, K., Iijima, M.2004. Crop production in successive wheat-soybean rotation with no-tillage practice in relation to the root system development. Plant Production Sciences, 7(3):329-336.

Khan, M.A.H., Parvej M.R.2010. Impact of conservation tillage under organic mulches on the reproductive efficacy and yield of quality protein maize. The Journal of Agricultural Sciences, 5(2): 52-63. 
Khandagave, R. B.2002. Influence of organic and inorganic manures on sugarcane and sugar yield. In: $64^{\text {th }}$ Annual Convention of the Sugar Technologists' Association of India, Cochin Kerala, A, 23-31.

Khurshid, K., Iqbal M., Arif M.S., Nawaz, A.2006. Effect of Tillage and Mulch on Soil Physical Properties and Growth of Maize. International Journal of Agriculture and Biology, 8(5):593-596.

Liu, J., Xu, S.A., Zhou, G.Y., Lu, H.H.2002. Effects of transplanting multi-cropping spring maize with plastic film mulching on the ecological effect, plant growth and grain yield. Journal of Hubei Agric.Collec, 2: 100.

Mesfine, T., Abebe, G., Rahman, A., Tawaha, M. Al.2005.Effect of Reduced Tillage and Crop Residue Ground Cover on Yield and Water Use Efficiency of Sorghum (Sorghum bicolor (L.) Moench) Under Semi-Arid Conditions of Ethiopia. World Journal of Agricultural Sciences, 1(2): 152-160.

Moreno, F., Pelegrin, F., Fernandez, J.E., Murillo, J.M., 1997. Soil physical properties, water depletion and crop development in southern Spain. Soil and Tillage Research, 41: 2542.

Motavalli, P.P., Stevens, W.E. and Hartwig, G. 2003. Remediation of subsoil compaction and compaction effects on corn $\mathrm{N}$ availability by deep tillage and application of poultry manure in a sandy-textured soil. Soil Tillage Research, 71(2): 121-131.

Okeleye, K.A. and Oyekanmi, A.A. 2003. Influence of tillage systems and nitrogen fertilizer levels on growth and yield of maize (Zea mays L.) hybrids. Moor Journal of Agricultural Research, 4(1): 26-36.

Parasuraman, P. 2002. Response of farming studies in rainfed finger millet (Eleusine coracana) under erratic monsoon conditions of north-western agroclimatic zone of Tamil Nadu. Indian Journal of Agronomy, 47(3): 384-389.

Patil, S.L., Sheelavantar, M.N., 2006. Soil water conservation and yield of winter sorghum (Sorghum bicolor L. Moench) as influenced by tillage, organic materials and nitrogen fertilizer in semi-arid tropical India. Soil and Tillage Research, 89(2): 246-257.

Pervaiz, M.A., Iqbal, M., Shahzad, K., Hassan, A.U., 2009. Effect of mulch on soil physical properties and N, P, K concentration in maize (Zea mays L.) shoots under two tillage systems. International Journal of Agriculture and Biology, 11(2): 119-124.

Ressia, J.M., Mendivil, G.O., Balbuena, R.H., Chidichimo, H.O. and Asborno, M. 2000. Effect of three tillage systems on penetration resistance, soil moisture and corn (Zea mays L.) growth. Agro-Ciencia, 16(2): 197-205.

Russel, E.W.1971. Soil structure. Its maintenance and improvement. Journal of Soil Science, 22: 137-151.

Sharma, P., Abrol, V., Sankar, G.R.M., Singh, B.2009. Influence of tillage practices and mulching options on productivity, economics and soil physical properties of maize (Zea mays)-wheat (Triticum aestivum) system. Indian Journal of Agricultural Sciences, 79 (11): 865-870.

Shittu, O.S., Fasina, A.S.2006. Comparative effect of different residue management on maize yield at Ado-Ekiti, Nigeria. Journal of Sustainable Agriculture, 28(2): 41-54. 
Shukla, L., Tyagi, S.P.2009. Effect of integrated application of organic manures on soil parameters and growth of mungbean (Vigna radiata). Indian Journal of Agricultural Sciences, 79 (3): 174-177.

Singh, R., Sharma, A.R., Dhyani, S.K. and Dube, R.K. 2011. Tillage and mulching effects on performance of maize (Zea mays)-wheat (Triticum aestivum) cropping system under varying land slopes. Indian Journal of Agricultural Sciences, 81 (4): 330-5.

Su, Z., Zhang, J., Wu, W., Cai, D., Lv, J., Jiang, G., Huang, J., Gao, J., Hartmann, R. and Gabriels, D. 2007. Effects of conservation tillage practices on winter wheat water-use efficiency and crop yield on the Loess Plateau, China. Agril. Water Mgt., 87(3): 307314.

Wang, X., Dai, K., Zhang, D., Zhang, X., Wang, Y., Zhao, Q., Cai, D., Hoogmoed, W.B., Oenema, O.2011. Dryland maize yields and water use efficiency in response to tillage/crop stubble and nutrient management practices in China. Field Crops Research, 120 (1): 47-57.

Yi, Z.X., Zhou, W.X., Tu, N.M., Tu, X.D., Wu, Y.L., Yang, W.L., 2007. Effects of no-tillage and straw mulching on soil nutrient content and drought resistance of maize on dry land. Research Agriculture Moder, 28(4): 490-493. 
Table 1(a): Effect of tillage, mulch and vermicompost on yield attributing characters of maize

\begin{tabular}{|c|c|c|c|c|c|c|c|c|}
\hline \multirow[b]{3}{*}{ Treatments } & \multicolumn{8}{|c|}{ Yield attributing characters } \\
\hline & \multicolumn{2}{|c|}{ 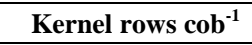 } & \multicolumn{2}{|c|}{ No. of kernels row ${ }^{-1}$} & \multicolumn{2}{|c|}{100 seed weight (g) } & \multicolumn{2}{|c|}{ No. of seeds cob $^{-1}$} \\
\hline & 2010 & 2011 & 2010 & 2011 & 2010 & 2011 & 2010 & 2011 \\
\hline \multicolumn{9}{|c|}{ Tillage system (C) } \\
\hline $\mathrm{C}_{1}$ & 14.70 & 15.54 & 35.29 & 35.58 & 22.75 & 22.69 & 513.9 & 551.3 \\
\hline $\mathrm{C}_{0}$ & 13.66 & 14.00 & 30.88 & 31.08 & 20.99 & 21.14 & 427.5 & 441.3 \\
\hline S.E. \pm & 0.59 & 0.72 & 1.42 & 1.43 & 0.81 & 0.53 & 36.22 & 39.77 \\
\hline C.D $(p=0.05)$ & N.S. & N.S. & N.S. & N.S. & N.S. & N.S. & N.S. & N.S. \\
\hline \multicolumn{9}{|c|}{ Mulch levels (M) } \\
\hline $\mathrm{M}_{1}$ & 14.37 & 15.29 & 35.21 & 35.46 & 22.43 & 22.54 & 506.7 & 544.6 \\
\hline $\mathrm{M}_{0}$ & 14.00 & 14.25 & 30.96 & 31.21 & 21.31 & 21.29 & 434.7 & 448.0 \\
\hline S.E. \pm & 0.14 & 0.21 & 0.54 & 0.461 & 0.53 & 0.23 & 11.05 & 12.07 \\
\hline C.D. $(p=0.05)$ & N.S. & 0.81 & 2.14 & 1.81 & N.S. & 0.88 & 43.37 & 47.39 \\
\hline \multicolumn{9}{|c|}{ Vermicompost (V) } \\
\hline $\mathrm{V}_{1}$ & 14.33 & 14.50 & 33.42 & 33.67 & 21.92 & 21.92 & 477.2 & 493.8 \\
\hline $\mathrm{V}_{2}$ & 14.33 & 14.92 & 34.50 & 34.67 & 22.37 & 22.33 & 499.0 & 522.1 \\
\hline $\mathrm{V}_{3}$ & 14.67 & 15.58 & 35.17 & 35.42 & 22.91 & 23.07 & 510.3 & 552.7 \\
\hline $\mathrm{V}_{4}$ & 13.42 & 14.08 & 29.25 & 29.58 & 20.26 & 20.36 & 396.4 & 416.6 \\
\hline S.E. \pm & 0.66 & 0.66 & 1.72 & 1.71 & 1.06 & 0.85 & 29.05 & 31.28 \\
\hline C.D. $(p=0.05)$ & N.S. & N.S. & N.S. & N.S. & N.S. & N.S. & 84.80 & 91.31 \\
\hline \multicolumn{9}{|c|}{$\mathrm{C} \times \mathrm{M}$} \\
\hline S.E. \pm & 0.60 & 0.74 & 1.52 & 1.50 & 0.97 & 0.57 & 37.86 & 41.56 \\
\hline C.D. $(p=0.05)$ & N.S. & N.S. & 8.81 & 8.85 & N.S. & N.S. & N.S. & N.S. \\
\hline \multicolumn{9}{|c|}{$\mathrm{C} \times \mathrm{V}$} \\
\hline S.E. \pm & 1.00 & 1.08 & 2.54 & 2.54 & 1.53 & 1.16 & 50.77 & 55.23 \\
\hline C.D. $(p=0.05)$ & N.S. & N.S. & N.S. & N.S. & N.S. & N.S. & N.S. & N.S. \\
\hline \multicolumn{9}{|c|}{$\mathbf{M} \times \mathbf{V}$} \\
\hline S.E. \pm & 0.82 & 0.83 & 2.17 & 2.15 & 1.40 & 1.06 & 37.26 & 40.17 \\
\hline C.D. $(p=0.05)$ & N.S. & N.S. & N.S. & N.S. & N.S. & N.S. & N.S. & N.S. \\
\hline
\end{tabular}


Table 1(b): Effect of tillage, mulch and vermicompost on yield attributing characters of maize

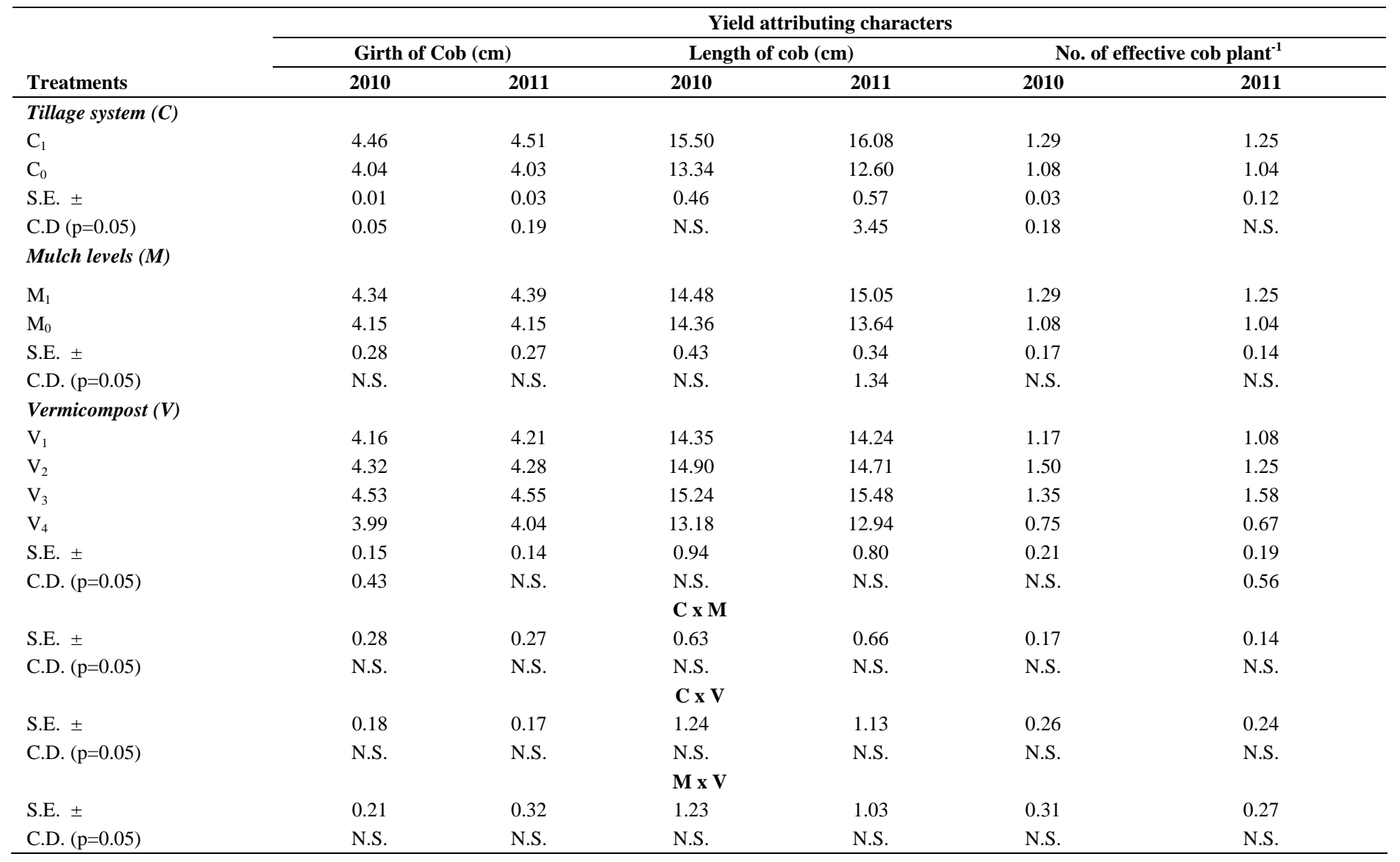

$\mathrm{C}_{0}=$ Zero tillage, $\mathrm{C}_{1}=$ Conventional tillage, $\mathrm{M}_{0}=$ Unmulched, $\mathrm{M}_{1}=$ Mulching, $\mathrm{V}_{1}=75 \% \mathrm{RD}+$ Vermicompost @ 5t ha ${ }^{-1}, \mathrm{~V}_{2}=75 \% \mathrm{RD}+\mathrm{Vermicompost}$ @ 7.5t ha $a^{-1}, \mathrm{~V}_{3}=75 \% \mathrm{RD}+$ Vermicompost @ 10t ha ${ }^{-1}, \mathrm{~V}_{4}=100 \% \mathrm{RD}, \mathrm{RD}=$ Recommended Dose of N, $\mathrm{P}_{2} \mathrm{O}_{5}$ and $\mathrm{K}_{2} \mathrm{O} @ 120: 60: 60$ Kg ha ${ }^{-1}$. 
Table 2: Effect of tillage, mulch and vermicompost on yield characters of maize

\begin{tabular}{|c|c|c|c|c|c|c|}
\hline \multirow[b]{3}{*}{ Treatments } & \multicolumn{6}{|c|}{ Yield Characters } \\
\hline & \multicolumn{2}{|c|}{ Grain yield $\left(\mathrm{Kg} \mathrm{ha}^{-1}\right)$} & \multicolumn{2}{|c|}{ Stover Yield $\left(\mathrm{Kg} \mathrm{ha}^{-1}\right)$} & \multicolumn{2}{|c|}{ Harvest Index (\%) } \\
\hline & 2010 & 2011 & 2010 & 2011 & 2010 & 2011 \\
\hline \multicolumn{7}{|c|}{ Tillage system (C) } \\
\hline $\mathrm{C}_{1}$ & 3305 & 3364 & 7565 & 7643 & 46.86 & 46.03 \\
\hline $\mathrm{C}_{0}$ & 3238 & 3297 & 6515 & 7115 & 33.53 & 32.00 \\
\hline S.E. \pm & 96.0 & 97.0 & 145.0 & 234.0 & & \\
\hline C.D (p=0.05) & N.S. & N.S. & N.S. & N.S. & & \\
\hline \multicolumn{7}{|c|}{ Mulch levels (M) } \\
\hline $\mathrm{M}_{1}$ & 3458 & 3465 & 7383 & 7626 & 41.53 & 39.58 \\
\hline $\mathrm{M}_{0}$ & 3084 & 3197 & 6698 & 7132 & 38.85 & 38.45 \\
\hline S.E. \pm & 47.0 & 58.0 & 146.0 & 121.0 & & \\
\hline C.D. $(p=0.05)$ & 183.0 & 229.0 & 572.0 & 475.0 & & \\
\hline \multicolumn{7}{|c|}{ Vermicompost (V) } \\
\hline $\mathrm{V}_{1}$ & 3171 & 3200 & 6843 & 7159 & 39.96 & 38.52 \\
\hline $\mathrm{V}_{2}$ & 3336 & 3388 & 7215 & 7726 & 40.61 & 38.97 \\
\hline $\mathrm{V}_{3}$ & 3646 & 3763 & 7860 & 8174 & 40.78 & 40.58 \\
\hline $\mathrm{V}_{4}$ & 2932 & 2973 & 6244 & 6456 & 39.41 & 38.01 \\
\hline S.E. \pm & 207.0 & 205.0 & 226.0 & 318.0 & & \\
\hline C.D. $(p=0.05)$ & 605.9 & 597.6 & 659.0 & 929.0 & & \\
\hline \multicolumn{7}{|c|}{ C $\times \mathbf{M}$} \\
\hline S.E. \pm & 107.0 & 112.0 & 206.0 & 264.0 & & \\
\hline C.D. $(p=0.05)$ & N.S. & N.S. & $\begin{array}{l}\text { N.S. } \\
\mathbf{C} \mathbf{x} \mathbf{V}\end{array}$ & N.S. & C x V & \\
\hline S.E. \pm & 271.0 & 269.0 & 313.0 & 455.0 & & \\
\hline C.D. $(p=0.05)$ & N.S. & N.S. & $\begin{array}{l}\text { N.S. } \\
\mathbf{M} \mathbf{x} \mathbf{V}\end{array}$ & N.S. & & \\
\hline S.E. \pm & 258.0 & 257.0 & 313.0 & 408.0 & & \\
\hline C.D. $(p=0.05)$ & N.S. & N.S. & N.S. & N.S. & & \\
\hline
\end{tabular}

$\mathrm{C}_{0}=$ Zero tillage, $\mathrm{C}_{1}=$ Conventional tillage, $\mathrm{M}_{0}=$ Unmulched, $\mathrm{M}_{1}=$ Mulching, $\mathrm{V}_{1}=75 \% \mathrm{RD}+$ Vermicompost @ 5t ha ${ }^{-1}$, $\mathrm{V}_{2}=75 \% \mathrm{RD}+\mathrm{Vermicompost}$ @ 7.5t ha ${ }^{-1}, \mathrm{~V}_{3}=75 \% \mathrm{RD}+$ Vermicompost @ 10t ha ${ }^{-1}, \mathrm{~V}_{4}=100 \% \mathrm{RD}, \mathrm{RD}=$ Recommended Dose of N, $\mathrm{P}_{2} \mathrm{O}_{5}$ and $\mathrm{K}_{2} \mathrm{O} @ 120: 60: 60$ Kg ha ${ }^{-1}$. 

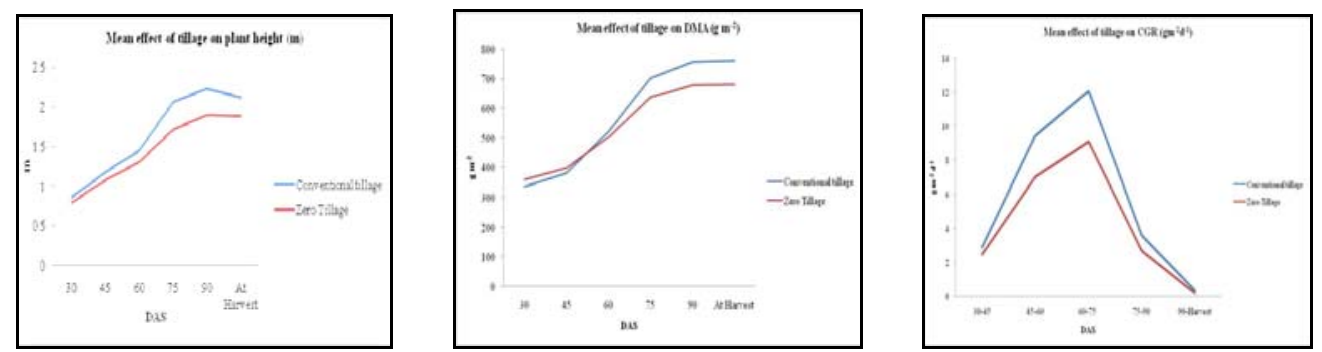

Figure 1: Two years mean effect of tillage, mulch and vermicompost on plant height
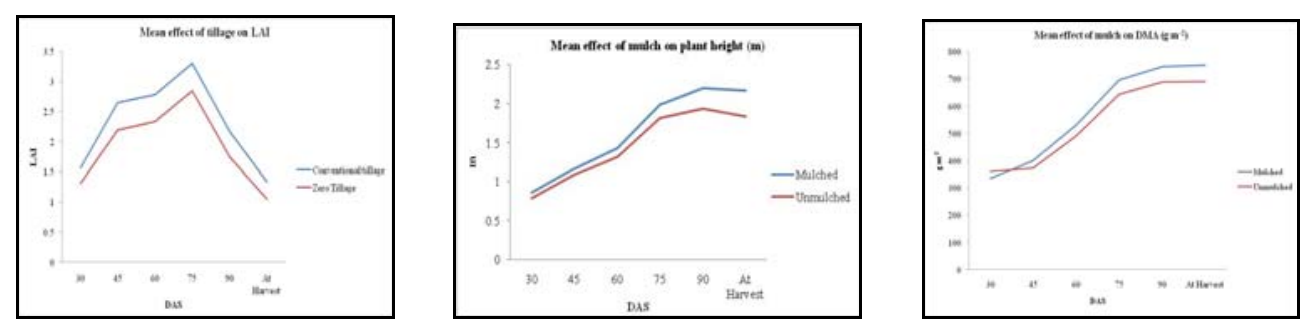

Figure 2: Two years mean effect of tillage, mulch and vermicompost on dry matter accumulation
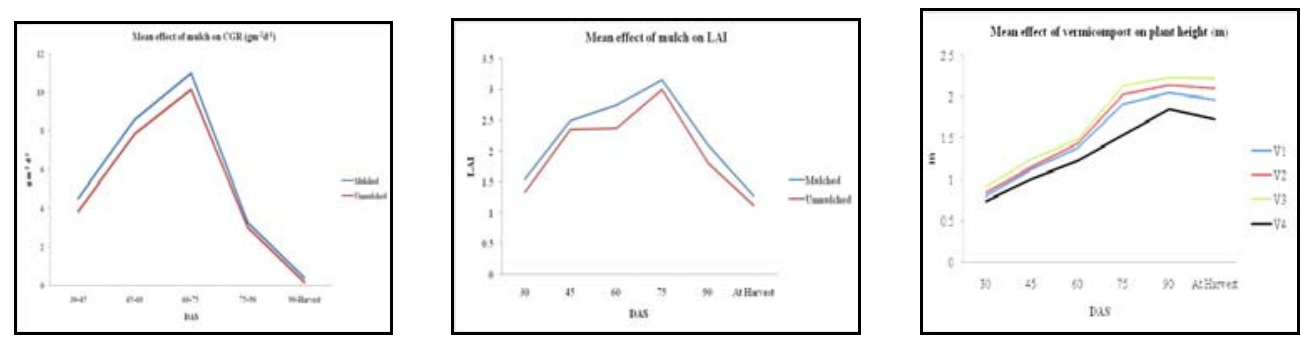

Figure 3: Two years mean effect of tillage, mulch and vermicompost on crop growth rate
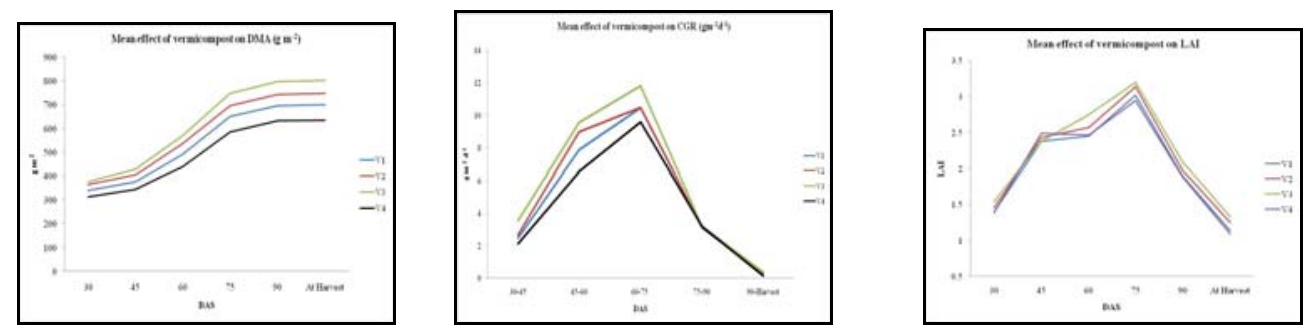

Figure 4: Two years mean effect of tillage, mulch and vermicompost on leaf area index 

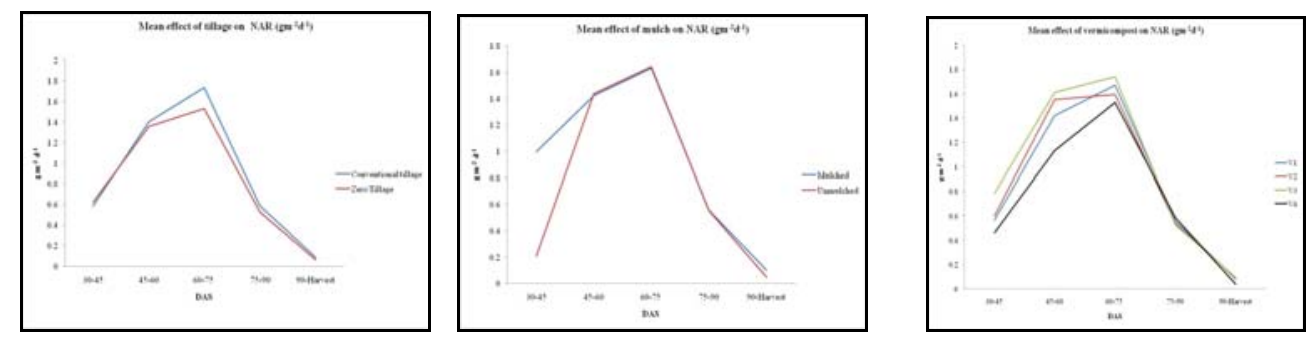

Figure 5: Two years mean effect of tillage, mulch and vermicompost on net assimilation rate 